Інна НАГРИБЕЛЬНА, orcid.org/0000-0001-6393-3754, доктор педагогічних наук, доиент, професор кафедри соиіально-гуманітарних дисциплін та інновачійної педагогіки Херсонської державної морської академії (Херсон, Україна) іnnanagribelna@gmail.com

\title{
МЕТОДИКА ФОРМУВАННЯ КОМУНІКАТИВНОЇ КОМПЕТЕНТНОСТІ МАЙБУТНІХ ФАХІВЦІВ МОРСЬКОЇ ГАЛУЗІ В СИСТЕМІ ВИЩОЇ ОСВІТИ
}

Матеріал статті репрезентує аналіз проблеми методики формування комунікативної компетентності майбутніх фахівиів морської галузі в системі вищої освіти. У статті акцентовано увагу на соціальних чинниках, щзо актуалізували потребу ї̈ формування в сучасних здобувачів освіти. До них віднесено такі: введення безвізового режиму з різними краӥнами, міграчійні прочеси, можливість навчання іноземних студентів в Украйні тощо. Відзначено серед інших чинників і діджиталізацію суспільства, як таку, щуо демонструє стрімкий технічний прогрес людства тощио.

Обгрунтовано потребу формування комунікативної компетентності у здобувачів освіти-майбутніх фахівців морської галузі. Визначено ключові чинники, щуо зумовлюють означену потребу, як-от: специфіку професійної діяльності майбутніх моряків як фахівиів, щчо працюють тривалий час в умовах закритого колективу; полікультурне професійне середовище; усвідомлення ролі комунікативної компетентності в професійних мовленнєвих ситуаиіях.

Акцентовано увагу на застосуванні комунікативного підходу до навчання здобувачів освіти, щуо передбачає створення та реалізацію комунікативних ситуацій, пов'язаних із професійною діяльністю. У дослідженні виділено такі: ділова комунікація зі стейкхолдером; команди на ходовому містку; комунікація вахтового офіцера з береговими службами під час стоянки у порту; комунікація вахтового помічника капітана судна з лоиманом; комунікація капітана судна із судновласником; комунікація бочмана із матросами під час проведення швартовних операцій.

Представлено конкретні приклади практичного впровадження означеного підходу засобом моделювання фахових ситуачій та методики «Хмари слів»; наведено демонстраційний матеріал для самооцінювання наявності (відсутності) показників комунікативної компетентності майбутніх фахівців морської галузі.

Описано специифіку моделювання комунікативних ситуацій, пов'язаних безпосередньо з виробничою діяльністю. Сучасним прикладом такого моделювання є робота майбутніх моряків на тренажерному комплексі «Віртуально-реальне судно», який дозволяє моделювати професійні комунікативні ситуації в умовах, наближених до реальності.

Ключові слова: фахівець морської галузі, комунікативна компетентність, мовленнєва ситуачія, тренажерний комплекс «Віртуально-реальне судно».

Inna NAHRYBELNA, orcid.org/0000-0001-6393-3754

Doctor of Pedagogical Science, Associate Professor, Professor at the Department of Social Sciences and Humanities and Innovative Pedagogy Kherson State Maritime Academy (Kherson, Ukraine) innanagribelna@gmail.com

\section{METHODS OF FORMATION OF COMMUNICATIVE COMPETENCE OF FUTURE SPECIALISTS OF THE MARITIME INDUSTRY IN THE SYSTEM OF HIGHER EDUCATION}

The material of the article represents the analysis of the problem of the method of formation of communicative competence of future specialists of the maritime branch in the system of higher education. The article pays attention to the social factors that actualized the need for its formation in modern students. These include: the introduction of a visafree regime with different countries, migration processes, the possibility of studying foreign students in Ukraine, and so on. Among other factors, the digitalization of society was noted as one that demonstrates the rapid technical progress of mankind and so on.

The need for the formation of communicative competence in students seeking education in the future of the maritime industry is substantiated. The key factors that determine this need are identified, in particular: due to a number of factors, 
such as the specifics of the professional activities of future seafarers as professionals working for a long time in a closed team; multicultural professional environment; awareness of the role of communicative competence in professional speech situations.

Emphasis is placed on the application of a communicative approach to the education of students, which involves the creation and implementation of communicative situations related to professional activities. The study identified the following: business communication with the stakeholder; commands on the gangway; communication of the watch officer with the shore services during the parking in the port; communication of the ship's captain's assistant with the pilot; communication of the ship's captain with the shipowner; communication of the boatswain with sailors during mooring operations.

Specific examples of practical implementation of this approach by means of modeling professional situations and methods of "Word Cloud" are presented; demonstration material for self-assessment of the presence (absence) of indicators of communicative competence of future specialists in the maritime industry is given.

The specifics of modeling communicative situations directly related to production activities are described. A modern example of such modeling is the work of future sailors on the training complex "Virtual-real ship", which allows you to simulate professional communication situations in conditions close to reality.

Key words: marine specialist; communicative competence; speech situation; training complex "Virtual-real ship".

Постановка проблеми. Стрімкий розвиток суспільства актуалізував проблему комунікації в різних соціальних сферах. Це зумовлено різними чинниками, зокрема введенням безвізового режиму з різними країнами, міграційними процесами громадян, можливістю навчання іноземних студентів в Україні тощо. Окремої уваги заслуговує і діджиталізація суспільства, яка демонструє стрімкий технічний прогрес людства. Водночас динамічні процеси інформатизації зумовлюють виникнення проблем вільного та грамотного спілкування людей у різних комунікативних ситуаціях.

Серед чинників, що актуалізують проблему комунікації, слід відзначити й соціальні перестороги, пов'язані з карантинними обмеженнями у зв'язку зі світовою пандемією COVID-19. Тут відмітимо введення змішаного та дистанційного навчання в освітніх закладах, а отже, і зміну комунікативної поведінки здобувачів освіти. Рекомендації лікарів щодо обмеження контактів також впливають на формування комунікативних навичок та подальший розвиток комунікативної компетентності мовця. Результатом різноманітних і динамічних змін стало полікультурне середовище, в якому комунікативні навички особистості набувають важливого значення.

Соціальні потреби декларують вимоги до посилення комунікативної грамотності в усіх ланках освіти: від початкової школи до ЗВО. Модернізація освітньої системи в Україні зумовила переосмислення методики формування комунікативної компетентності здобувачів освіти та вибір методично доцільних засобів навчання комунікативної грамотності. Особливої актуальності набуває дана проблема в контексті аналізу вищої освіти та виокремлення комунікативної компетентності як важливого складника в професійній підготовці фахівця.

Активно досліджується порушене питання в методиці фахової підготовки майбутніх учителів різних профілів. Вивчається комунікативний підхід у навчанні майбутніх фахівців деревообробної, фармацевтичної галузей. У науковому доробку вчених знаходимо дослідження проблеми комунікації в іноземних здобувачів вищої освіти.

Водночас залишається малодослідженим аспект, що зумовив постановку проблеми дослідження: методика формування комунікативної компетентності майбутніх фахівців морської галузі. Недостатня наукова увага до порушеного питання викликає певний подив 3 огляду на те, що в Україні достойно представлена фахова підготовка спеціалістів морської галузі.

Аналіз тенденцій вступних кампаній до закладів вищої морської освіти в Україні вказує на стабільно високий попит на професії в галузі «Морський та річковий транспорт» за спеціалізаціями «Навігація і управління морськими суднами» та «Управління судновими технічними системами та комплексами». Це вказує на необхідність аналізу стану сформованості комунікативних навичок у цієї категорії здобувачів освіти та застосування ефективних засобів навчання для формування й розвитку в них комунікативної компетентності в подальшій фаховій діяльності.

Аналіз досліджень підтвердив, що проблема формування комунікативної компетентності завжди викликала інтерес у науковій площині. У різних аспектах їі досліджували в галузі комунікативної лінгвістики, психолінгвістики та лінгводидактики. На сучасному етапі дослідження проблеми комунікативної компетентності мовця науковою увагою охоплено різні вікові, соціальні та професійні групи людей.

Вивчення джерельної бази засвідчило, що в наукових доробках українських та зарубіжних учених представлено чимало актуальних розвідок щодо проблеми комунікативної компетентності мовця. Теоретично і практично значущими є праці 
вітчизняних учених Р. Дружненко (Дружненко, 2016: 205-211), I. Нагрибельної (Нагрибельна, 2016: 233) Н. Сіранчук (Сіранчук, 2017), О. Семиног (Семиног, 2010), Т. Симоненко (Симоненко, 2005: 40-43), Л. Суботи (Субота, 2017), Л. Рускуліс (Рускуліс, 2018) та ін.

У межах аналізу проблеми дослідження цінними виявилися праці вчених, що репрезентують вузькоспеціальний аспект проблеми фахової підготовки моряків. Так, наприклад, нам імпонує думка про те, що в сучасних закладах морської освіти навчання спрямовано на формування ключових компетентностей, які виділено Сврокомісією (Нагрибельний, 2019: 233). Із-поміж базових компетентностей майбутнього моряка, як-от технічної, природничо-наукової, математичної, визначено й комунікативну. Сформованість усіх означених компетентностей, як підкреслює у своїй монографії Я. Нагрибельний, «активно сприяє забезпеченню якісної підготовки майбутніх фахівців та професійної готовності» (Нагрибельний, 2019: 233). У сучасних наукових розвідках учених знаходимо таке бачення: «...оскільки Україна входить до п'ятірки лідерів країн-постачальників командного персоналу для світового торгового флоту, то формування ключових компетентностей студентів морських спеціальностей набуває особливої актуальності» (Нагрибельний, 2019: 233).

Студіювання проблеми комунікативної компетентності дозволило констатувати наявність авторитетного наукового підгрунтя для іiї багатоаспектного розроблення. Полівекторність проблеми підтверджують праці, що присвячені методиці формування комунікативної компетентності в системі вищої освіти. Усвідомлення означеного вплинуло на вибір теми наукового пошуку та означило його мету.

Мета статті - проаналізувати проблему методики формування комунікативної компетентності в майбутніх фахівців морської галузі.

Відповідно до мети дослідження було визначено низку завдань:

- проаналізувати сутність ключових дефініцій порушеної проблеми;

- обгрунтувати необхідність формування комунікативної компетентності у здобувачів вищої освіти - майбутніх фахівців морської галузі;

- дослідити методичну інноватику в процесі формування комунікативної компетентності у майбутніх спеціалістів морської галузі.

Виклад основного матеріалу. Огляд літератури 3 порушеної в статті проблеми підтвердив, що проблема комунікативної компетентності та методики іiі формування є полівекторною кате- горією. У межах предмету аналізу комунікативної компетентності науково значущим виявилося дослідження Л. Рускуліс, в якому проаналізовано методичну систему формування лінгвістичної компетентності майбутніх учителів української мови в процесі вивчення мовознавчих дисциплін (Рускуліс, 2018: 183). Дослідниця визначила чітку ієрархію структурних компонентів лінгвістичної компетентності. Нам імпонує iі наукова позиція щодо мотиваційної сфери студента в процесі формування складників лінгвістичної компетентності, серед яких комунікативна займає важливий ступінь (Рускуліс, 2018: 183-185).

У монографії Н. Сіранчук, що присвячена формуванню лексичної компетентності молодших школярів на уроках української мови, обгрунтовано основні принципи розвитку мовлення особистості, починаючи 3 початкової школи. Для нашого дослідження важливим $\epsilon$ трактування авторкою лексичної компетентності мовця як передумови успішного формування комунікативних умінь та навичок (Сіранчук, 2017: 38-43). Уважаємо слушною думку про те, що сформовані в початковому курсі української мови лексичні знання стають міцним підгрунтям для подальшого формування та вдосконалення лексичного словника особистості. Нам видається, що розвинений активний словниковий запас значно спрощує в подальшому мовленнєву поведінку людини та сприяє вільному володінню мовою в різних комунікативних ситуаціях.

Досліджуючи самостійну роботу в системі підготовки майбутніх учителів початкових класів до навчання української мови, ми представили розлоге наукове бачення комунікативної компетентності майбутнього фахівця початкової школи, визначивши іiі так: «...це здатність розуміти чужі й створювати власні програми мовленнєвої поведінки, адекватні меті, сфері, ситуації спілкування» (Нагрибельна, 2016: 67).

Слушною є думка Т. Симоненко про те, що комунікативна компетентність зумовлюється фаховою діяльністю. Наприклад, комунікативна компетентність учителя, на думку вченої, «зумовлюється гуманістичною спрямованістю освіти, здатністю відчувати іншу людину, адекватно сприймати іï, бути готовим до співпраці, взаємодії» (Симоненко, 2005: 40-43).

У науковому доробку Л. Суботи репрезентовано дослідження комунікативного підходу до навчання дискурсу іноземних студентів. Для нашого дослідження цінним $є$ аналіз комунікативної організації наукового тексту в методиці викладання української мови як іноземної. Нам 
імпонує думка авторки про доцільність застосування комунікативного підходу в процесі роботи з науковими текстами (Субота, 2017: 98-112). Така позиція дослідниці видається обгрунтованою, адже робота $з$ науковими текстами у вищій школі домінує над іншими. 3 огляду на означене застосування комунікативного підходу під час опанування фахових наукових текстів $є$ методично доцільним.

Огляд наукової літератури дозволяе констатувати актуальність та поліфункціональність досліджуваної категорії. У площині теорії та методики навчання української мови проблема комунікативної компетентності, формування сучасної мовної особистості завжди викликала дискусії. Це свідчить про теоретичну та практичну значущість досліджуваного явища. Наукові позиції сучасних українських учених демонструють різнобічні уявлення про комунікативну компетентність. Водночас усі вони обстоюють спільну позицію про провідну роль комунікативної компетентності під час орієнтації в мовленнєвих ситуаціях, у процесі оволодіння правилами комунікативної поведінки та виборі вербальних або невербальних мовновиражальних засобів.

Потреба формування та вдосконалення комунікативної компетентності майбутнього фахівця морської галузі зумовлена низкою чинників:

- специфікою професійної діяльності майбутніх моряків як фахівців, що працюють тривалий час в умовах закритого колективу;

- полікультурним фаховим середовищем;

- усвідомленням ролі комунікативної компетентності в професійних мовленнєвих ситуаціях.

У системі вищої морської освіти формування та вдосконалення комунікативної компетентності відбувається в площині загальнонавчальної та фахової підготовки. Водночас не викликає сумнівів той факт, що «Українська мова (за професійним спрямуванням)» як освітня компонента має найбільший навчальний потенціал для формування й розвитку мовної особистості майбутнього моряка. Це зумовлено метою, завданням курсу та освітніми можливостями лінгвістичного матеріалу, що вивчається.

Особливої уваги набуває методика формування комунікативної компетентності майбутнього фахівця морської галузі, яка передбачає адекватну комунікативну поведінку здобувача освіти, його вміння володіти мовою в різних комунікативних ситуаціях, доцільно користуватися активним лексичним словником тощо. 3 огляду на означене постає необхідність у доборі та практичному застосуванні на заняттях 3 української мови сучасних методичних засобів, які би відповідали поставленим вимогам.

В ієрархії української лінгводидактики пріоритетну роль має визначення підходу до навчання. Покликаючись на обгрунтовані погляди вчених, що представлені в дослідженні, ми вважаємо доцільним застосування комунікативно-діяльнісного підходу в навчанні майбутніх фахівців морської галузі. Упровадження означеного підходу до навчання здобувачів освіти передбачає створення та реалізацію комунікативних ситуацій, пов'язаних із професійною сферою. Досвід власної викладацької діяльності переконує в тому, що найбільш ефективними $\epsilon$ ті комунікативні ситуації, що максимально наближені до реальних умов роботи. У дослідженні до них відносимо такі:

- ділова комунікація зі стейкхолдером;

- команди на ходовому містку;

- комунікація вахтового офіцера 3 береговими службами під час стоянки в порту;

- комунікація вахтового помічника капітана судна $з$ лоцманом;

- комунікація капітана судна із судновласником;

- комунікація боцмана 3 матросами під час проведення швартовних операцій.

Розглянемо створення таких комунікативних ситуацій на прикладі освітнього процесу в Херсонській державній морській академії (ХДМА).

У структурі ХДМА ефективно працює сучасний тренажерний комплекс «Віртуально-реальне судно», який дозволяє моделювати означені та інші професійні комунікативні ситуації в умовах, наближених до реальності. Проілюструємо це детальніше на прикладі виробничої ситуації, що моделюється на віртуальних тренажерах «Повнофункціональний навігаційний місток» та на тренажері «Машинне відділення». Сутність виробничої діяльності на цих тренажерах передбачає комунікацію, що полягає в наданні команд із судового містка про певні дії судновому вахтовому механіку. Логіка дій останнього підкріплюється доцільними командами, які пов'язані з рухом та логістикою судна.

Результат виконання поставленої професійної задачі вимірюється в тому числі набуттям комунікативної компетентностіздобувача освіти. Це виявляється в умінні чітко та точно поставити завдання екіпажу; логічно та доступно сформулювати можливі ризики 3 метою їх запобігання; дібрати адекватні ситуації мовленнєві стимули; вибрати правильний тон і стиль спілкування, не принижуючи гідності окремих членів екіпажу тощо.

Для того щоб здобувачі освіти могли усвідомити позитивні та негативні моменти 
власної комунікативної поведінки, їм пропонується таблиця для самооцінювання, яка містить показники сформованості комунікативної компетентності.

\begin{tabular}{|l|c|c|}
\hline $\begin{array}{c}\text { Показники комунікативної } \\
\text { компетентності }\end{array}$ & $\begin{array}{c}\text { Наявні } \\
(+)\end{array}$ & $\begin{array}{c}\text { Відсутні } \\
(-)\end{array}$ \\
\hline Правильність мовлення & & \\
\hline Точність & & \\
\hline Ясність & & \\
\hline Доступність & & \\
\hline Логічність & & \\
\hline Естетичність & & \\
\hline Чистота & & \\
\hline Багатство & & \\
\hline Виразність & & \\
\hline Доречність & & \\
\hline
\end{tabular}

Прикладом методичної інноватики в процесі формування комунікативної компетентності майбутнього фахівця морської галузі є застосування методики «Хмари слів».

У науковій літературі представлено тлумачення цієї методики навчання як такої, що «спрямована на розвиток лексичної грамотності, активізацію словникового запасу та формування контекстуального мовлення» (Нагрибельна, 2020: 110-113). У площині лінгводидактики хмару слів розглядають, як «візуалізацію слів (тегів) за певним принципом» (Нагрибельна, 2020: 110-113).

На заняттях з курсу «Українська мова (за професійним спрямуванням)» впровадження такого методичного засобу навчання $є$ доцільним у процесі опанування професійної лексики, ï тлумачення, перекладу, введення в контекстуальне мовлення. Репрезентуємо приклад хмари (тегів) слів-професіоналізмів:

Хмара слів: стерновий, итурвал, суднонафтозбирач, лочія, кіль, плавальний цеенз, логістика, кнехт, брашпиль, якірний ланцюг, клюз, ходові вогні, бак, гірокомпас, ехолот, шпангоут, трюм, гвинт регульованого кроку, румб.

До представленої хмари слів здобувачам освіти може бути запропоновано такий методичний апарат:

1. Укладіть речення зі словами-термінами, пояснивши їхне лексичне значення.

2. Визначте, які з представлених слів є багатозначними. Укладіть речення, в яких ключові слова використано в одному випадку в прямому значенні, а в іншому - у переносному.

3. Поміркуйте, чому більшість термінів із наведеної хмари слів є іншомовними. 3 якої мови в украӥнську лексику «прийшли» иі слова? Чи $є$ цьвому пояснення, щзо пов'язане зі світовою історією, історією мореплавства, історією мови?
Упровадження таких завдань розвиває вже набуті мовленнєві навички та формує професійну комунікативну поведінку здобувача освіти.

Прикметно, що застосування представлених комунікативно-орієнтованих завдань та вправ сприяє активізації творчо-пізнавальної діяльності курсантів (студентів), стимулює до розв'язання проблемних ситуацій, формує доцільну комунікативну поведінку.

Висновки. У результаті роботи над темою дослідження було зроблено висновки:

1. Аналіз науково-методичної літератури підтвердив актуальність проблеми формування комунікативної компетентності сучасної мовної особистості та дозволив виокремити наукові позиції вчених щодо тлумачення сутності комунікативної компетентності та іiї ролі в професійній діяльності. Визначено, що соціальні потреби декларують вимоги до вищої освіти щодо підготовки фахівця, який демонструє сформовану комунікативну компетентність у різних мовленнєвих ситуаціях.

2. Обгрунтовано необхідність формування комунікативної компетентності у здобувачів вищої освіти - майбутніх фахівців морської галузі 3 огляду на низку чинників. Серед них пріоритетними визначено такі, як специфіка професійної діяльності майбутніх моряків як фахівців, що працюють тривалий час в умовах закритого колективу; полікультурне фахове середовище; усвідомлення ролі комунікативної компетентності в професійних мовленнєвих ситуаціях.

3. Проаналізовано інноваційні методичні засоби навчання, що використано в процесі формування комунікативної компетентності у майбутніх спеціалістів морської галузі. Акцентовано увагу на методично доцільних засобах комунікативно-орієнтованого навчання майбутніх фахівців морської галузі на заняттях 3 курсу «Українська мова (за професійним спрямуванням)». У межах предмету аналізу виокремлено такі, як моделювання комунікативних ситуацій та методика «Хмари слів».

Репрезентовано специфіку впровадження комунікативних ситуацій в умовах роботи майбутніх фахівців морської галузі на тренажерному комплексі «Віртуально-реальне судно»; представлено способи самоперевірки здобувачів освіти щодо наявності або відсутності в них показників сформованості комунікативної компетентності.

Отже, аналіз джерельної бази дослідження, усвідомлення соціальних потреб щодо формування сучасної мовної особистості та власний досвід викладання у вищій школі дозволили констатувати доцільність активного впровадження 
сучасних комунікативно орієнтованих сучасних засобів навчання в процесі професійної підготовки майбутніх фахівців морської галузі. Репре- зентоване в дослідженні питання не вичерпує повністю порушену проблему, а є одним із перспективних аспектів її розроблення.

\section{СПИСОК ВИКОРИСТАНИХ ДЖЕРЕЛ}

1. Дружненко Р. Дидактичні основи комунікативно-прагматичної компетентності майбутнього вчителя української мови і літератури. Науковий вісник Миколаӥвського наиіонального університету імені В.О. Сухомлинського. Педагогічні науки : зб. наук. праць. Миколаїв : МНУ імені В.О. Сухомлинського, 2016. № 3 (54). Вересень. С. 205-211.

2. Нагрибельна I. А. Методична інноватика в навчанні початкового курсу української мови. URL: http://journals.uran.ua/index.php/2308-4855/article/view/204653

3. Нагрибельна I. А. Самостійна робота в системі підготовки майбутніх учителів початкових класів до навчання української мови : монографія. Херсон, 2016. 310 с.

4. Нагрибельний Я. А. Становлення і розвиток змісту історії педагогіки в освітній парадигмі незалежної України (1991-2019pр.) : монографія. Кропивницький : Видавець Лисенко В.Ф., 2019. 274 с.

5. Сіранчук Н. М. Формування лексичної компетентності в учнів початкових класів на уроках української мови : монографія. Київ : «Центр учбової літератури», 2017. 288 с.

6. Семеног О. М. Культура наукової української мови : навчальний посібник. Київ : ВЦ «Академія», 2010. 216 с.

7. Симоненко Т. М. Базова система вправ у роботі над розвитком професійно-комунікативних умінь студентівфілологів. Украӥнська мова і література в школі. 2005. № 7. С. 40-43.

8. Субота Л. А. Комунікативний підхід до навчання наукового дискурсу іноземних студентів : монографія. Харків : Майдан, 2017. 408 c.

9. Рускуліс Л. В. Методична система формування лінгвістичної компетентності майбутніх учителів української мови у процесі вивчення мовознавчих дисциплін : монографія, Миколаїв : ФОП Швець В.М., 2018. 420 с.

\section{REFERENCES}

1. Druzhnenko R. Dydaktychni osnovy komunikatyvno-prahmatychnoyi kompetentnosti maybutn'oho vchytelya ukrayins'koyi movy i literatury. [Didactic bases of communicative-pragmatic competence of the future teacher of Ukrainian language and literature.] Scientific Bulletin of Nikolaev National University named after VO Sukhomlinsky. Pedagogical sciences: coll. Science. wash. Mykolaiv: MNU named after VO Sukhomlinsky, 2016. №3 (54), September. pp.205-211[in Ukrainian].

2. Nahrybelna I. A. Metodychna innovatyka $v$ navchanni pochatkovoho kursu ukrayins'koyi movy [Methodical innovation in teaching the initial course of the Ukrainian language]. Access mode: http://journals.uran.ua/index.php/2308-4855/ article/view/204653[in Ukrainian].

3. Nahrybelna I. A. Samostiyna robota $v$ systemi pidhotovky maybutnikh uchyteliv pochatkovykh klasiv do navchannya ukrayins'koyi movy [Independent work in the system of preparation of future primary school teachers for teaching the Ukrainian language] [monograph] / I. A. Nagrybelna. Kherson, 2016. 310 p. [in Ukrainian].

4. Nagrybelnyi Ya. A. Stanovlennya i rozvytok zmistu istoriyi pedahohiky v osvitniy paradyhmi nezalezhnoyi Ukrayiny (1991-2019 rr.) [Formation and development of the content of the history of pedagogy in the educational paradigm of independent Ukraine (1991-2019).] Monograph. Kropyvnytskyi: Publisher Lysenko V.F., 2019. 274 p. [in Ukrainian].

5. Siranchuk N. M. Formuvannya leksychnoyi kompetentnosti v uchniv pochatkovykh klasiv na urokakh ukrayins'koyi movy. [Formation of lexical competence in primary school students in Ukrainian language lessonsi]] Monograph. Siranchuk. Kyiv: "Center for Educational Literature", 2017. 288 p. [in Ukrainian].

6. Semenoh O. M. Kul'tura naukovoyi ukrayins'koyi movy: navchal'nyy posibnyk. [The culture of the scientific Ukrainian language: a textbook.] Kyiv: VC "Academy", 2010. 216 p. [in Ukrainian].

7. Symonenko T. M. Bazova systema vprav u roboti nad rozvytkom profesiyno-komunikatyvnykh umin' studentiv-filolohiv [Basic system of exercises in the work on the development of professional and communicative skills of students-philologists] / Tetyana Symonenko // Ukrainian language and literature at school. 2005. № 7. P. 40-43. [in Ukrainian].

8. Subota L. A. Komunikatyvnyy pidkhid do navchannya naukovoho dyskursu inozemnykh studentiv [Communicative approach to teaching scientific discourse of foreign students]: monograph / Larisa Andreevna Subota. Kharkiv: Maidan, 2017. 408 p. [in Ukrainian].

9. Ruskulis L. V. Metodychna systema formuvannya linhvistychnoyi kompetentnosti maybutnikh uchyteliv ukrayins'koyi movy u protsesi vyvchennya movoznavchykh dystsyplin [Methodical system of formation of linguistic competence of future teachers of the Ukrainian language in the process of studying linguistic disciplines]: monograph, Mykolaiv: FOP Shvets V. M., 2018. 420c. [in Ukrainian]. 